\title{
PENGEMBANGAN MODUL PEMBELAJARAN MATA KULIAH INTERNET OF THINGS
}

\author{
Anak Agung Gde Ekayana1), Anak Agung Ratna Rakasiwi²) \\ 1 Sistem Komputer, STMIK STIKOM Indonesia \\ 2 Teknik Informatika, STMIK STIKOM Indonesia \\ Email: gungekayana@stiki-indonesia.ac.id, ratnaraka@stiki-indonesia.ac.id
}

\begin{abstract}
ABSTRAK
Penelitian ini bertujuan menghasilkan modul pembelajaran untuk mata kuliah Internet of Things, modul yang disusun berupa modul cetak. Modul ini disusun karena didasari perubahan kurikulum yang ada di Program Studi Sistem Komputer STMIK STIKOM Indonesia, adanya perubahan kurikulum tentunya ada beberapa penambahan matakuliah baru, salah satunya Internet of Things (IoT). Implikasi dari pengembangan kurikulum berdampak pula pada proses pembelajaran, sehingga dipandang perlu untuk menyusun materi menjadi sebuah sumber belajar yang relevan, salah satunya berupa modul pembelarajran. Metode yang digunakan dalam pengembangan modul ini adalah model pengembangan ADDIE, model ini digunakan karena tahapan pengembangannya lebih sederhana dan waktu yang digunakan tidak terlalu lama. Hasil dari penelitian ini berupa modul pembelajaran loT versi cetak, untuk menentukan kelayakan penggunaan modul ini telah dilakukan uji coba, antara lain uji coba perorangan dan uji coba kelompok kecil. Pada pengujian perorangan melibatkan 3 orang mahapeserta didik Sistem Komputer yang diambil secera acak dan sudah pernah mengambil Mata Kuliah loT, sedangkan pengujian kelompok kecil melibatkan 9 orang mahapeserta didik Sistem Komputer. Hasil dari uji coba tersebut adalah pada uji coba perorangan memperoleh hasil rerata $91,94 \%$ dan uji coba kelompok kecil memperoleh $86,67 \%$, selanjutnya angka tersebut dimasukkan pada tabel skor kelayakan kontinum dan hasilnya menyatakan bahwa modul pembelajaran Internet of Things dianggap layak digunakan dalam proses pembelajaran.
\end{abstract}

Kata kunci: modul pembelajaran, iot, addie

\begin{abstract}
This study aims to produce a learning module for the Internet of Things course, a module compiled in a print module. This module is structured because it is based on curriculum changes in the STMIK STIKOM Indonesia Computer System Study Program, there is certainly a change in curriculum, there are some new courses added, one of them is the Internet of Things (IOT). The implications of curriculum development also have an impact on the learning process, so it is deemed necessary to compile material into a relevant learning resource, one of which is a learning module. The method used in developing this module is the ADDIE development model, this model is used because the development stages are simpler and the time used is not too long. The results of this study were in the form of a printed version of IOT learning module, to determine the feasibility of using this module a trial was conducted, including individual trials and small group trials. In individual testing involving 3 students and students of Computer Systems taken randomly and have taken IoT courses, while small group testing involves 9 students and students of Computer Systems. The results of these trials were that individual trials obtained an average yield of $91.94 \%$ and a small group trial obtained $86.67 \%$, then the number was included in the continuum score score table and the results stated that the Internet of Things learning module was considered appropriate for learning process.
\end{abstract}

Keywords : learning module, loT, addie) 


\section{PENDAHULUAN}

Proses belajar merupakan dasar dari setiap manusia untuk bisa menggali potensi yang ada pada dirinya, dengan kegiatan belajar setiap orang mampu mengoptimalkan kemampuan untuk menjadi yang lebih baik dari sebelumnya, pendidikan juga memberikan kontribusi dalam pembentukan kualitas sumber daya[1]. Sejak sekolah dasar hingga Perguruan Tinggi, setiap anak tentu di didik untuk menjadi yang lebih baik dari sebelumnya, dengan harapan masa depan yang lebih cerah untuk kemudian hari. Dibalik pendidikan yang memberikan ilmu pengetahuan untuk setiap orang, tentunya ada rencana yang disusun agar tujuan yang dicita-cita dapat tercapai. Kurikulum merupakan seperangkat rencana dan pengaturan yang digunakan oleh setiap satuan pendidikan dalam mengajarkan dan mentransformasikan ilmu pengetahuan kepada setiap peserta didik. Kurikulum disiapkan untuk mencetak generasi dalam menghadapi tantangan masa depan. Proses pembelajaran merupakan bagian dari implementasi pendidikan, dimana berlangsung rutinistas yang dilakukan oleh pengajar untuk berinteraksi positif dengan peserta didik, dalam pembelajaran yang dilakukan di Kampus STMIK STIKOM Indonesia sudah menerapkan pembelajaran berbasis student center. Pembelajaran student center menerapkan proses pembelajaran yang lebih aktif dari peserta didik, dengan mengedepankan aspek kreatifitas, inovatif, produktif dan afektif. Beranjak dari peraturan yang dikeluarkan oleh Kementerian Riset dan Pendidikan Tinggi terkait perubahan kurikulum yang terbaru yaitu Kurikulum KKNI, dimana didalam kurikulum tersebut mengedepankan kompetensi lulusan/capaian pembelajaran. Implikasi dengan diterapkan kurikulum $\mathrm{KKNI}$ tentunya ada pengembangan yang terjadi pada kurikulum sebelumnya. Pengembangan Kurikulum kearah KKNI mengakibatkan ada penambahan dan pengurangan matakuliah. Pada program studi Sistem Komputer terdapat penambahan matakuliah salah satunya Internet of Things (IOT), alasan mata kuliah loT dimasukkan pada kurikulum adalah aplikasi teknologi yang sedang berkembang menuju era Revolusi buku ajar, modul, handout masih belum tersedia. Kurangnya sumber belajar yang digunakan berdampak pada materi yang diajarkan menjadi tidak terstruktur dan kurang relevan. Berdasarkan keadaan yang dipaparkan diatas, dipandang perlu untuk mengadakan suatu sumber belajar dalam mata kuliah internet of things, agar dalam proses pembelajaran mengarah pada tujuan yang sudah direncanakan. Salah satu solusi yang dapat dilakukan adalah inovasi dalam penyusunan sumber belajar menjadi sebuah modul pembelajaran. Modul pembelajaran mendukung prinsip learning by doing dan individualized leaning[2]. Pada peta kerucut pengalaman Hidgar Dale, pengalaman belajar langsung dan mandiri akan memberikan kesan paling utuh dan paling bermakna mengenai informasi dan gagasan yang terkandung pada pengalaman itu. Pada penelitian yang dilakukan Ramadhana, dkk menjelaskan bahwa modul yang dikembangkan dengan pendekatan tertentu dapat memberikan hasil yang lebih efektif kepada peserta didik[3], hal senada juga dijelaskan pada penelitian dari Kalsum,dkk bahwa penggunaan modul yang dirancang dengan menggunakan pendekatan CTL dapat membantu peserta didik dalam proses pembelajaran, dan modul yang dirancang perlu senantiasa di kembang untuk dapat mengakomodasi semua peserta didik[4].

Modul merupakan salah satu bahan ajar yang dapat membantu peserta didik maupun pengajar dalam proses pembelajaran, karena dengan modul peserta didik dapat mengajar dirinya sendiri dan melakukan kontrol sendiri terhadap intensitas belajarnya. Beberapa penelitian yang relevan mengai modul pembelajaran memberikan hasil yang positif untuk proses pembelajaran. Penelitian yang dilakukan Mahendra,dkk juga memberikan hasil yang baik pada penggunaan modul pembelajaran untuk media pembelajaran[5]

\section{A. Pembelajaran Konstruktivistik}

Konstruktivistik dikembangkan oleh Piaget pada pertengahan abad-20. Piaget berpendapat bahwa pada dasarnya setiap individu kecil sudah memiliki kemampuan untuk mengkontruksi pengetahuan sendiri. Pengetahuan yang dikontruksi oleh anak sebagai objek, maka menjadi pengetahuan yang bermakna; sedangkan pengetahuan yang hanya diperoleh melalui proses pemberitahuan tidak akan menjadi pengetahuan yang bermakna. Pengetahuan tersebut hanya untuk diingat sementara setelah itu dilupakan[6].

Teori konstruktivis menyatakan bahwa peserta didik harus menemukan sendiri dan mentransformasikan informasi kompleks, mengecek informasi baru dengan aturan-aturan lama dan merevisinya apabila aturan-aturan itu tidak lagi sesuai. Menurut teori konstruktivis ini, satu prinsip yang paling penting dalam psikologi pendidikan adalah bahwa Pengajar tidak sekedar memberikan pengetahuan kepada peserta didik. Peserta didik harus membangun sendiri pengetahuan di dalam benaknya. Pengajar dapat memberikan kemudahan untuk proses ini, dengan memberikan kesempatan peserta didik untuk menemukan atau menerapkan ide-ide mereka sendiri, dan mengajar 
peserta didik menjadi sadar dan secara sadar menggunakan strategi mereka sendiri untuk belajar. Pengajar dapat memberikan peserta didik anak tangga yang membawa peserta didik ke pemahaman yang lebih tinggi, dengan catatan peserta didik sendiri yang harus memanjat anak tangga tersebut.

\section{B. Media Cetak}

Media cetak merupakan pengajaran terprogram yang berbentuk buku. Buku yang dimaksud pada penelitian ini merupakan modul pembelajaran yang berisi prosedur materi mata kuliah Internet of Things serta memuat materi, tugas, dan tes yang dirancang secara sistematis dan menarik untuk mencapai kompetensi yang diharapkan sesuai dengan tingkat kompleksitasnya dan termasuk kedalam jenis media cetak berwujud modul.

Menurut pedoman penulisan modul yang dikeluarkan Direktorat Tenaga Kependidikan Direktorat Jendral Peningkatan Mutu Pendidik Dan Tenaga Kependidikan Departemen Pendidikan Nasional, Sebuah modul bisa dikatakan baik dan menarik apabila terdapat karakteristik sebagai berikut[7]:

\section{a) Self instructional}

Melalui penggunaan modul, siswa mampu belajar secara mandiri dan tidak selalu tergantung pada guru maupun pihak lainnya. Untuk memenuhi karakter Self Instructional maka dalam modul harus memenuhi kriteria (1) memuat tujuan yang dirumuskan dengan jelas, (2) memuat materi pembelajaran yang dikemas kedalam unit-unit kecil sehingga memudahkan belajar secara tuntas, (3) memuat contoh dan ilustri yang mendukung kejelasan pemaparan meteri pembelajaran, (4) memuat latihan soal dan tugas yang memungkinkan siswa memberikan respon dan dapat mengukur tingkat penguasaannya, (5) memuat permasalahan kontekstual, (6) menggunakan bahasa yang sederhana dan komunikatif, (7) memuat rangkuman materi pembelajaran, (8) memuat instrumen penilaian yang memungkinkan penggunaan melakukan Self assessment, (9) memuat umpan balik atas penilaian, sehingga penggunaannya mengetahui tingkat penguasaan materi, (10) menyediakan informasi tentang rujukan atau referensi yang mendukung materi pembelajaran dan modul.

\section{b) Self Contained}

Seluruh materi pembelajaran dari satu unit kompetensi atau sub kompetensi yang dipelajari terdapat di dalam suatu modul secara utuh. Tujuan dari konsep ini adalah memberi kesempatan sisiwa untuk belajar secara tuntas dan modul bisa memuat rangkaian kegiatan belajar yang direncanakan dan sistematis.

\section{c) Adaftive}

Modul dapat menyusun perkembangan ilmu pengetahuan dan teknologi, serta fleksibel digunakan, ini merupakan suatu modul yang dikatakan Adaftive. Selain itu modul yang adaptive adalah jika isi materi pembelajaran dapat digunakan sampai dengan kurun waktu tertentu.

\section{d) User Friendly}

Modul harus memiliki sifat bersahabat dengan pemiliknya, dengan kata lain modul harus mudah dipahami sehingga memudahkan siswa untuk memahami dari isi modul yang sudah disediakan, sehingga tidak hanya sebagai buku pegangan saja namun juga sebagai pegangan dan buku pelajaran yang harus dipelajari.

Penulisan modul merupakan proses penyusunan materi pembelajaran yang dikemas secara sistematis sehingga siap dipelajari oleh pebelajar untuk mencapai kompetensi atau sub kompetensi. Penyusunan modul belajar mengacu pada kompetensi yang terdapat di dalam tujuan yang ditetapkan.

Menurut Depdiknas, tahapan pengembangan modul, yaitu: analisis kebutuhan modul, penyusunan draf, uji coba, validasi dan revisi. Tahapan dalam penyusunan modul ditampilkan pada Gambar 1. 


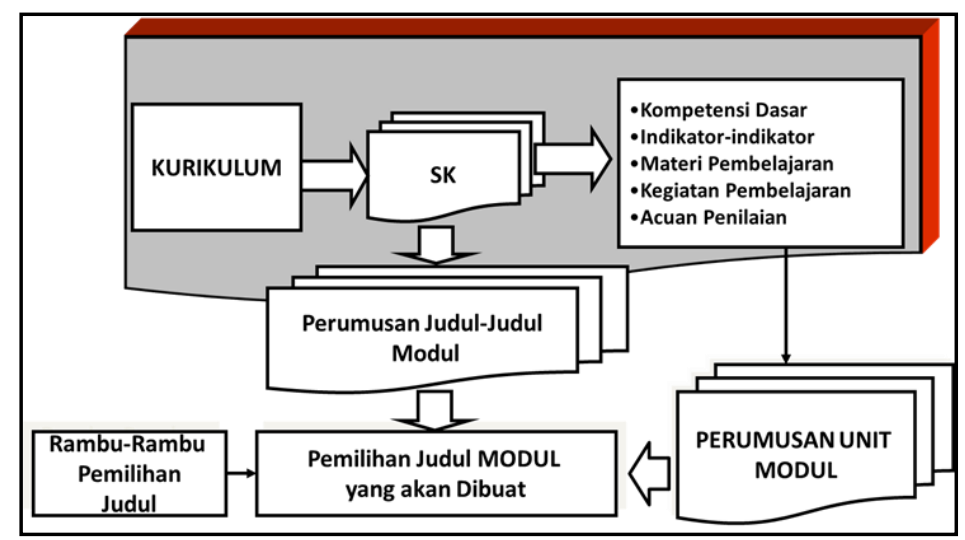

Gambar 1. Tahapan Penyusunan Modul Pembelajaran

Sumber: Departemen Pendidikan Nasional

\section{Internet of Things}

Internet of Things (IOT) adalah jaringan fisik atau "benda" yang dikoneksikan dengan perangkat elektronik, perangkat lunak,sensor dan konektivitas yang digunakan untuk mengaktifkan layanan pertukarah data dengan perangkat lain yang terhubung. Setiap hal dalam loT unik untuk diidentifikasi melalui sistem komputasi yang tertanam yang dapat berinteroperasi dalam Internet dengan adanya infrastruktur[8].

"A Things" pada Internet of Things dapat didefinisikan sebagai subjek misalkan orang dengan monitor implant jantung, hewan peternakan dengan transponder biochip, sebuah mobil yang telah dilengkapi built-in sensor untuk memperingatkan pengemudi ketika tekanan ban rendah. Sejauh ini, IoT paling erat hubungannya dengan komunikasi machine-to-machine (M2M) di bidang manufaktur dan listrik, perminyakan, dan gas. Produk dibangun dengan kemampuan komunikasi M2M yang sering disebut dengan sistem cerdas atau "smart". Sebagai contoh yaitu smart kabel, smart meter, smart grid sensor.

\section{METODE}

Penelitian ini merupakan penelitian pengembangan (Research and Development), dengan alasan karena sesuai dengan tujuan yang hendak dicapai. Metode penelitian pengembangan adalah metode peneltiian yang digunakan untuk menghasilkan produk tertentu[9]. Penelitian dan pengembangan adalah pembangunan berbasis industri, temuan penelitian digunakan untuk merancang produk dan prosedur baru, kemudian dilakukan uji lapangan secara sistematis, dievaluasi dan disempurnakan sampai diketahui efektivitas, kualitas, atau standar yang sama dari kreteria yang ditentukan[10]. Perangkat yang dikembangkan adalah modul cetak untuk mata kuliah Internet of Things.

Kegiatan penelitian yang dilakukan tidak terlepas dari penelitian yang sudah ada sebelumnya, sehingga perlu adanya review dari beberapa penelitian terdahulu sebagai bahan kreativitas dan inovasi kedepannya, adapun penelitian yang relevan, antara lain: Penelitian dari Fahrizal, dkk (2016) berjudul "Penggunaan Modul Pembelajaran Berbasis Komputer (CAD) untuk Meningkatkan Hasil Belajar di SMK negeri 3 Jombang" memberikan hasil dalam penggunaan modul pembelajaran dalam ranah kognitif mencapai $80 \%$, ranah psikomotor mencapai $100 \%$, dan respon terhadap penggunaan modul mencapai 91,33\% [11]. Penelitian dari Siahaan (2017) berjudul "Pengembangan Modul Pembelajaran pada Kompetensi Autocad Siswa SMK" memberikan hasil bahwa modul yang disusun sudah baik dan layak digunakan dalam pembelajaran berdasarkan respon dari ahli materi dan desain. Hasil lain juga diberikan bahwa dalam penggunaan modul pembelajaran memiliki keefektifan lebih tinggi dalam proses belajar[12]. Berdasarkan hasil penelitian terdahulu yang relevan, penulis dalam penelitian ini mengembangkan modul pembelajaran untuk memberikan materi-materi yang sistematis dalam proses belajar dalam mendukung pengembangan kurikulum KKNI.

Model pengembangan yang digunakan adalah model ADDIE. Model ini sesuai dengan namanya, terdiri dari lima tahap utama, yaitu (A)nalysis, (D)esign, (D)evelopment, (I)mplementation, dan (E)valuation. Model desain sistem pembelajaran ADDIE dengan komponen- komponennya dapat digambarkan dalam diagram berikut: 


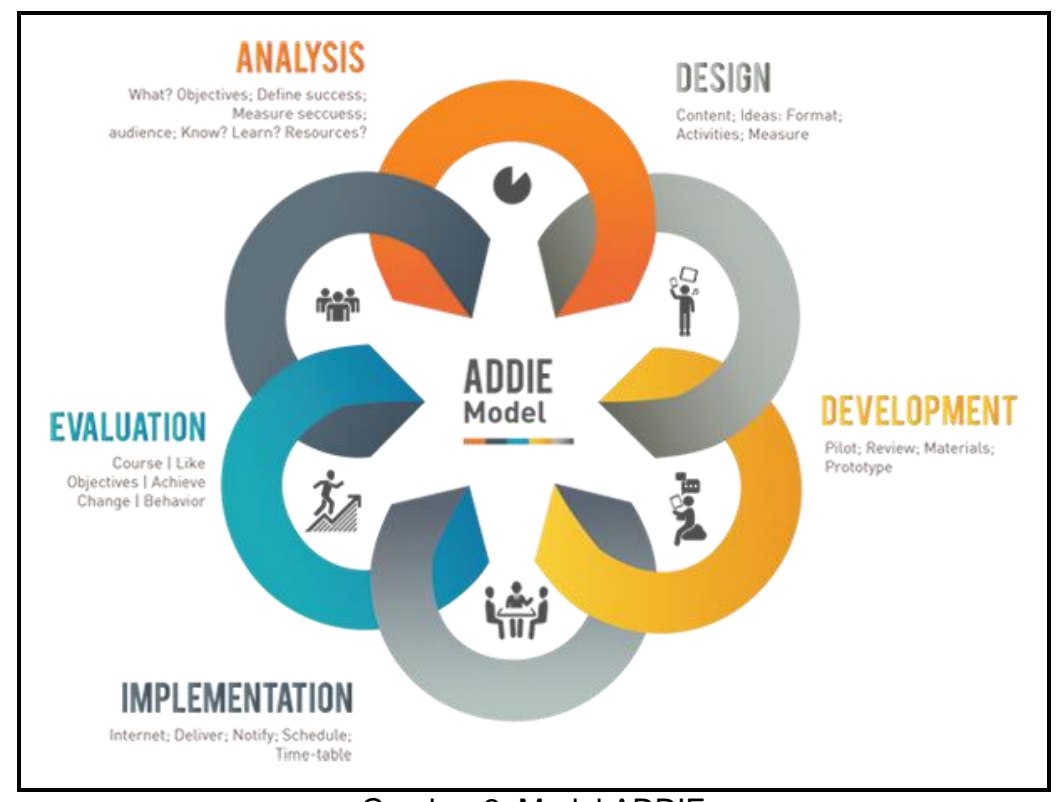

Gambar 2. Model ADDIE

(sumber: http://nadya22ula.blogspot.com/2017/10/dr-dirgantara-wicaksono-mpd-mm-tugas.html)

\section{A. Analysis}

Tahap analisis merupakan suatu proses mendefinisikan apa yang akan dipelajari oleh mahasiswa, yaitu melakukan needs assessment (analisis kebutuhan), mengidentifikasi masalah (kebutuhan), dan melakukan analisis tugas (task analysis). Oleh karena itu, output yang akan kita hasilkan adalah berupa karakteristik atau profile calon peserta belajar, identifikasi kesenjangan, identifikasi kebutuhan dan analisis tugas yang rinci didasarkan atas kebutuhan.

\section{B. Design}

Tahap ini dikenal juga dengan istilah membuat rancangan (blueprint). Ibarat bangunan, maka sebelum dibangun gambar rancang bangun (blue-print) diatas kertas harus ada terlebih dahulu. Pertama merumuskan tujuan pembelajaran yang SMAR (spesifik, measurable, applicable, dan realistic). Selanjutnya menyusun tes, dimana tes tersebut harus didasarkan pada tujuan pembelajaran yag telah dirumuskan tadi. Kemudian tentukanlah strategi pembelajaran yang tepat harusnya seperti apa untuk mencapai tujuan tersebut,dalam hal ini ada banyak pilihan kombinasi metode dan media yang dapat kita pilih dan tentukan yang paling relevan. Disamping itu, pertimbangkan pula sumbersumber pendukung lain, semisal sumber belajar yang relevan, lingkungan belajar yang seperti apa seharusnya, dan lainlain. Semua itu tertuang dalam sautu dokumen bernama blueprint yang jelas dan rinci.

\section{Development}

Pengembangan adalah proses mewujudkan blue-print alias desain tadi menjadi kenyataan. Artinya, jika dalam desain diperlukan suatu software berupa multimedia pembelajaran, maka multimedia tersebut harus dikembangkan. Atau diperlukan modul cetak, maka modul tersebut perlu dikembangkan. Begitu pula halnya dengan lingkungan belajar lain yang akan mendukung proses pembelajaran semuanya harus disiapkan dalam tahap ini. Satu langkah penting dalam tahap pengembangan adalah uji coba sebelum diimplementasikan. Tahap uji coba ini memang merupakan bagian dari salah satu langkah ADDIE, yaitu evaluasi. Lebih tepatnya evaluasi formatif, karena hasilnya digunakan untuk memperbaiki sistem pembelajaran yang sedang kita kembangkan.

\section{Implementation}

Implementasi adalah langkah nyata untuk menerapkan sistem pembelajaran yang sedang kita buat. Artinya, pada tahap ini semua yang telah dikembangkan diinstal atau diset sedemikian rupa sesuai dengan peran atau fungsinya agar bisa diimplementasikan. Misal, jika memerlukan software tertentu maka software tersebut harus sudah diinstal. Jika penataan lingkungan harus tertentu, maka lingkungan atau seting tertentu tersebut juga harus ditata. Barulah diimplementasikan sesuai skenario atau desain awal. 


\section{E. Evaluasi}

Evaluasi adalah proses untuk melihat apakah sistem pembelajaran yang sedang dibangun berhasil, sesuai dengan harapan awal atau tidak. Sebenarnya tahap evaluasi bisa terjadi pada setiap empat tahap di atas. Evaluasi yang terjadi pada setiap empat tahap diatas itu dinamakan evaluasi formatif, karena tujuannya untuk kebutuhan revisi. Misal, pada tahap rancangan, mungkin kita memerlukan salah satu bentuk evaluasi formatif misalnya review ahli untuk memberikan input terhadap rancangan yang sedang kita buat. Pada tahap pengembangan, mungkin perlu uji coba dari produk yang kita kembangkan atau mungkin perlu evaluasi kelompok kecil. Modul yang telah disusun selanjutnya diuji cobakan kepada responden dan setelah itu diberikan angket/kuesioner untuk dapat menganalisis kelayakan modul sebagai perangkat pembelajaran

Terdapat dua macam data penelitian yang diklasifikasikan berdasarkan sifatnya yaitu data kualitatif dan data kuantitatif. Data kualitatif berupa masukan, saran, komentar terhadap modul yang dikembangkan. Sedangkan data kuantitatif berupa data hasil lembar observasi yang diberikan pada validator ahli materi, ahli media/desain. Data kuantitatif juga didapatkan dari hasil angket uji coba modul pada skala kecil dan skala menengah.

Jenis instrumen yang digunakan untuk memperoleh data yang sesuai dengan permasalahan adalah sebagai berikut:

\section{a) Lembar Validasi}

Lembar validasi digunakan untuk memvalidasi modul hasil pengembangan. Lembar validasi ini diberikan kepada para validator ahli materi, validator ahli desain/media. Ahli materi dan praktisi pendidikan/guru bidang studi memberikan penilaian terhadap aspek kelayakan isi, aspek kelayakan penyajian, dan aspek kelayakan bahasa. Validator ahli media/desain memberikan penilaian terhadap ukuran modul, desain sampul modul (cover), desain isi modul.

\section{b) Angket Responden}

Angket digunakan untuk mendapatkan data kuantitatif. Angket ini diberikan pada mahasiswa untuk mengetahui bagaimana respon siswa terhadap modul yang dikembangkan. mahasiswa diminta memberikan penilaian terhadap aspek tampilan, aspek penyajian materi dan aspek bahasa.

Teknik analisa data dalam penelitian ini dilakukan dengan menggunakan analisa kualitatif dan analisa kuantitatif.

1. Analisis kualitatif pada penelitian ini adalah analisis yang digunakan untuk menganalisis data kualitatif seperti masukan dan saran dari validator ahli materi dan ahli media/desain.

2. Analisis kuantitatif digunakan untuk mengkaji data lembar validasi diisi oleh validator ahli materi, validator ahli media/desain dan responden.

Analisis deskriptif kuantitatif digunakan untuk memaparkan mengenai kelayakan produk untuk diimplementasikan pada modul pembelajran matakuliah Internet of Things.

Data kuantitatif diperoleh menggunakan skala Likert. Skala Likert memiliki gradasi dari sangat positif sampai sangat negatif yang dapat diwujudkan dalam beragam kata-kata. Tingkatan bobot nilai yang digunakan sebagai skala pengukuran adalah $4,3,2,1$.

Dari data instrumen penelitian, kemudian dengan melihat bobot tiap tanggapan yang dipilih atas tiap pernyataan, selanjutnya menghitung skor rata-rata hasil penilaian tiap komponen perangkat pembelajaran dengan menggunakan rumus.

Validator ahli materi, ahli desain dan responden mengisi lembar validasi berdasarkan kriteria pada Tabel 1 berikut ini.

Tabel 1. Kriteria Penilaian Butir Lembar Validasi

\begin{tabular}{ccc}
\hline No & Kategori & Skor \\
\hline 1 & Sangat Baik & 4 \\
2 & Baik & 3 \\
3 & Kurang & 2 \\
4 & Sangat Kurang & 1 \\
\hline
\end{tabular}
berikut:

Rumus yang digunakan untuk menghitung persentase dari masing-masing subjek sebagai 


$$
P=\frac{\sum x}{\sum X i} x 100 \%
$$

Keterangan:

$$
\begin{array}{ll}
\mathrm{P} & =\text { Persentase yang dicari } \\
\Sigma \mathrm{X} & =\text { Jumlah Skor } \\
\Sigma \mathrm{Xi} & =\text { Skor Maksimal Ideal }
\end{array}
$$

Untuk memberikan makna dan pengambilan keputusan dari skor hasil perhitungan yang telah didapatkan diatas, skor dapat ditafsirkan dengan rentang seperti pada Tabel 2 dibawah ini.

Tabel 2. Kriteria Skor Angket Responden

\begin{tabular}{cc}
\hline Presentase & Kriteria \\
\hline $85-100 \%$ & Sangat Baik \\
$69-84 \%$ & Baik \\
$53-68 \%$ & Cukup \\
$37-52 \%$ & Kurang \\
$21-36 \%$ & Sangat Kurang \\
\hline
\end{tabular}

\section{HASIL DAN PEMBAHASAN}

\section{A. Hasil Penelitian}

Tahap awal yang dilakukan dalam menyusun modul pembelajaran adalah mempelajari kurikulum KKNI yang digunakan pada Prodi Sistem Komputer. Kurikulum menjadi panduan dalam menyusun suatu modul pembelajaran, karena di dalam kurikulum terdapat aturan-aturan yang harus diperhatikan, yaitu standar kompetensi, kompetensi dasar, indikator-indikator, tujuan pembelajaran, materi pembelajaran, kegiatan pembelajaran dan acuan penilaian.

Tahap kedua, yaitu perumusan judul modul yang akan menjadi cover depan dari isi modul. Pemilihan judul disesuaikan dengan materi yang akan diberikan dalam proses pembelajaran. Materi yang diambil adalah materi kuliah Internet of Things, sehingga judul yang diangkat adalah Modul Pembelajaran Internet of Things.

Setelah judul ditetapkan, langkah selanjutnya adalah mengidentifikasi Kompetensi dasar, aspek materi, kegiatan pembelajaran dan indikator serta penilaian. Proses mengidentifikasi materi dalam penyusunan modul, diperlukan referensi pendukung seperti halnya, panduan penyusunan modul dari Depdiknas, buku penyusunan bahan ajar, contoh modul yang sudah ada dan format penulisan Modul. Bila semua bahan atau referensi telah tersedia maka dilanjutkan dengan penyusunan draft modul.

Modul yang telah selesai disusun, selanjutnya dilakukan pengecekan terhadap outline, ukuran font, jenis font, komposisi ruang, warna, gambar pada materi dan kelengkapan isi materi, itu semua dilakukan agar modul yang disusun minim dari kesalahan dan menjadikan daya tarik kepada mahasiswa untuk mempelajarinya.

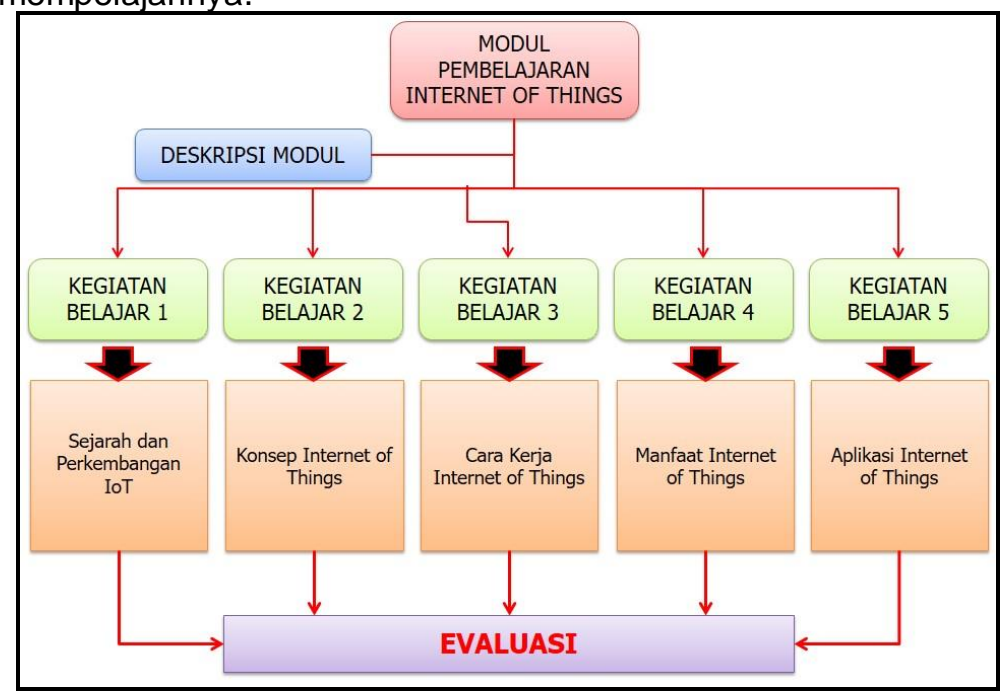

Gambar 3. Peta Konsep Materi Pada Modul 
Langkah selanjutnya adalah mencetak modul, modul yang telah selesai dikoreksi ulang dan diperbaiki bila ada yang salah, selanjutnya dicetak sesuai dengan ukuran yang sudah ditentukan. Modul dicetak sesuai kebutuhan, untuk persiapan uji coba awal, berikut desain cover modul pembelajaran ditampilkan pada Gambar 3.
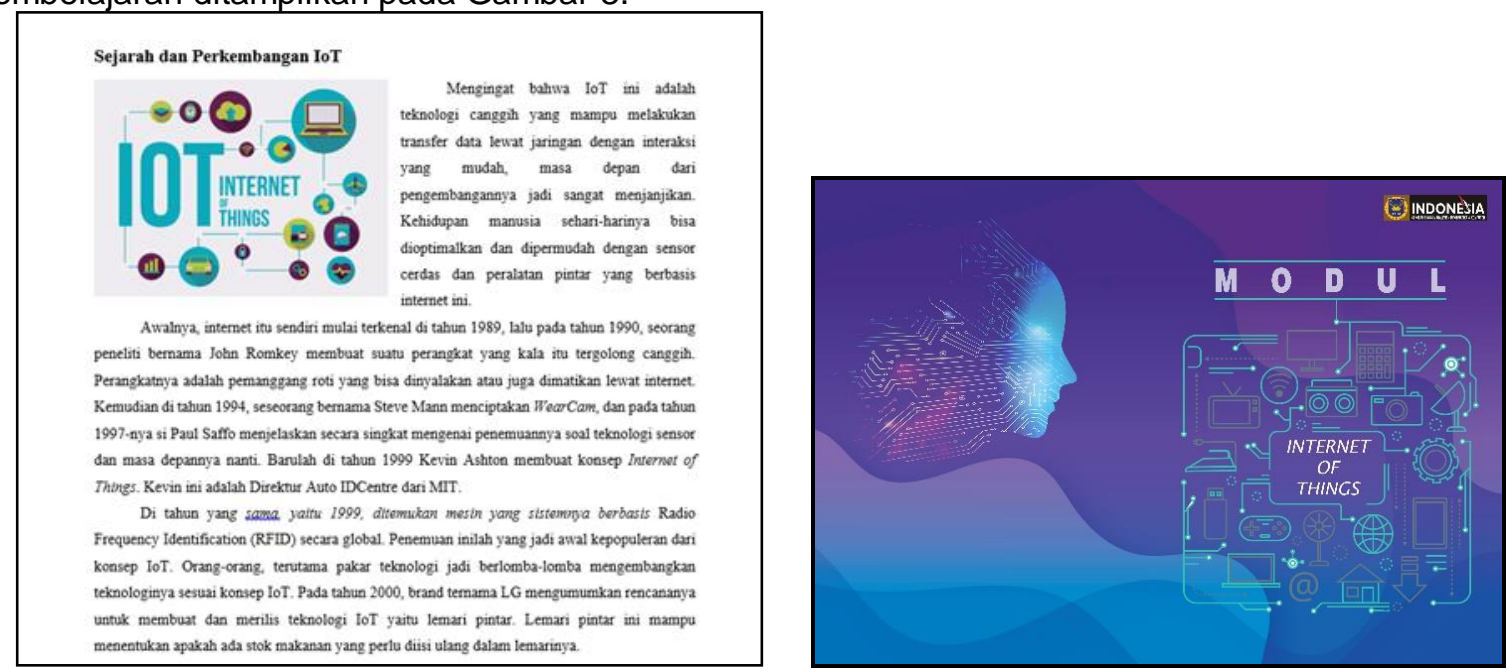

Gambar 4.(kiri) Contoh isi materi modul pembelajaran dan (kanan) Desain Cover Modul Pembelajaran

\section{B. Hasil Validasi}

Pada tahap validasi produk melibatkan ahli materi dan ahli desain, ahli materi melibatkan seorang Dosen yang memiliki kompetensi terkait isi dari modul pembelajaran Internet of Things, ahli isi pada modul ini adalah Kepala Program Studi Sistem Komputer. Adapun hasil dari ahli materi sebagai berikut:

Tabel 3. Hasil Evalusi Ahli Materi

\begin{tabular}{llll}
\hline No & \multicolumn{1}{c}{ Isi Pembelajaran } & \multicolumn{2}{c}{ Tanggapan } \\
\cline { 3 - 3 } 1 & Sejarah dan Perkembangan Internet of Things & Sesuai & Tidak Sesuai \\
2 & Konsep Internet of Things & $\sqrt{ }$ \\
3 & Cara kerja Internet of Things & $\sqrt{ }$ \\
4 & Manfaat Internet of Things & $\sqrt{ }$ \\
5 & Aplikasi Internet of Things & $\sqrt{ }$ \\
\hline
\end{tabular}

Evaluasi dalam penilaian oleh ahli materi yaitu melihat langsung produk modul pembelajaran. Seperti pengembangan pada umumnya, pengembangan modul ini tidak lepas dari kekurangan. Pada evaluasi ahli isi pembelajaran terdapat saran yaitu memperbaiki kesalahan-kesalahan ketik yang ada pada modul pembelajaran. Berdasarkan saran atau komentar tersebut penulis mengkoreksi kesalahan-kesalahan ketik yang ada pada modul, guna memperbaiki dan menyempurnakan produk modul pembelajaran. Komentar lisan dari ahli isi terhadap modul, yaitu produk media sudah bagus dan produk modul sudah memanfaatkan secara optimal teknologi yang sedang berkembang untuk proses pembelajaran Internet of Things.

Pada evaluasi media pada modul pembelajaran melibatkan seorang ahli desain yang merupakan salah satu Dosen Desain/Seni di Kampus STMIK STIKOM Indonesia. Adapun saran dan komentar yang diberikan adalah pada modul pembelajaran desain sudah baik, layout sudah tersusun rapi dan baik, perpaduan warna pada modul sudah sesuai standar, dari beberapa evaluasi masih terdapat kesalahan-kesalahan ketik, berdasarkan saran tersebut penulis melakukan revisi terhadap kesalahan-kesalahan kata yang terdapat pada modul. Hasil validasi dari ahli media ditampilkan pada Tabel 4. 
Tabel 4. Hasil Evaluasi Ahli Media

\begin{tabular}{lccccr}
\hline & \multicolumn{4}{c}{ INDIKATOR } & \multicolumn{1}{c}{ JUMLAH } \\
\cline { 2 - 5 } & SS & S & CS & TS & \\
Bobot & 4 & 3 & 2 & 1 & \\
Skor Item & 22 & 8 & 0 & 0 & 112 \\
Jumlah & 88 & 24 & 0 & 0 & $93,3 \%$ \\
Skor Total & & & & & 9 \\
\hline
\end{tabular}

Untuk pengambilan keputusan maka nilai total ini dikonversi ke pedoman Kriteria Skor Angket Responden skala lima yang disajikan pada Tabel 5 berikut.

Tabel 5. Konversi Kriteria Skor Angket

\begin{tabular}{ccl}
\hline Presentase & Kriteria & \multicolumn{1}{c}{ Keterangan } \\
\hline $85-100 \%$ & Sangat Baik & Tidak perlu direvisi \\
\hline $69-84 \%$ & Baik & Tidak perlu direvisi \\
\hline $53-68 \%$ & Cukup & Direvisi \\
\hline $37-52 \%$ & Kurang & Direvisi \\
\hline $21-36 \%$ & Sangat Kurang & Direvisi \\
\hline
\end{tabular}

Setelah hasil evaluasi dikonversi ke dalam skala 5 , rentang skor total $(93,3 \%)$ hasil tanggapan ahli media terhadap modul pembelajaran ada pada kualifikasi sangat layak/baik tidak perlu direvisi.

Tahap selanjutnya setelah melakukan perbaikan produk awal adalah melakukan uji coba lapangan. Dalam uji coba lapangan dilakukan 2 proses pengujian yaitu uji perorangan (3 orang responden), uji kelompok kecil (9 orang responden). Pada uji coba lapangan ini melibatkan mahasiswa Program Studi Sistem Komputer.

\section{a) Uji Coba Perorangan}

Pada uji coba perorangan produk modul pembelajaran dikemas dalam bentuk media cetak dan dijilid rapi untuk menambah daya tarik mahasiswa. Pada uji ini melibatkan mahasiswa Prodi Sistem Komputer sebanyak 3 (tiga) orang mahasiswa, yang sudah pernah mendapatkan materi Internet of Things. Hasil rekapitulasi uji perorangan terhadap modul pembelajaran Internet of Things dijabarkan pada Tabel 6 dibawah ini.

\begin{tabular}{|c|c|c|c|c|c|}
\hline & \multicolumn{4}{|c|}{ INDIKATOR } & \multirow[t]{2}{*}{$J U M L A H$} \\
\hline & SS & $\mathrm{S}$ & $\overline{C S}$ & $\overline{T S}$ & \\
\hline Bobot & 4 & 3 & 2 & 1 & \\
\hline Skor Item & 20 & 10 & 0 & 0 & 30 \\
\hline Jumlah & 80 & 30 & 0 & 0 & 110 \\
\hline Skor Total & & & & & $91,67 \%$ \\
\hline \multicolumn{6}{|c|}{$x 2$} \\
\hline & \multicolumn{4}{|c|}{ INDIKATOR } & $J U M L A H$ \\
\hline & SS & $\mathrm{S}$ & $\mathrm{CS}$ & TS & \\
\hline Bobot & 4 & 3 & 2 & 1 & \\
\hline Skor Item & 18 & 12 & 0 & 0 & 30 \\
\hline Jumlah & 72 & 36 & 0 & 0 & 108 \\
\hline Skor Total & & & & & $90,00 \%$ \\
\hline
\end{tabular}




\begin{tabular}{lllllr}
\hline & \multicolumn{4}{c}{ INDIKATOR } & JUMLAH \\
\cline { 2 - 5 } & SS & S & CS & TS & \\
Bobot & 4 & 3 & 2 & 1 & \\
Skor Item & 23 & 7 & 0 & 0 & 30 \\
Jumlah & 92 & 21 & 0 & 0 & 113 \\
Skor Total & & & & & $94,17 \%$ \\
\hline
\end{tabular}

Rerata Skor : $91.94 \%$

Setelah hasil rekapitulasi dari rerata skor dikonversi, rentang rerata skor $(91,94 \%)$ hasil dari uji coba perorangan ada pada kualifikasi sangat layak/baik tidak perlu direvisi.

Pada saat uji coba perorangan diberikan beberapa komentar diantaranya: produk yang dikembangkan sangat bagus, dengan produk ini kami (mahasiswa) menjadi lebih tertarik dalam mempelajari materi internet of things, modul yang dikembangkan membuat kami menjadi lebih cepat memahami suatu materi yang diberikan, dikarenakan terdapatnya contoh-contoh (real application) yang dapat digunakan sebagai visualisasi/simulasi tentang apa yang telah dipelajari

\section{b) Uji Coba Kelompok Kecil}

Pada uji coba kelompok kecil melibatkan 9 mahasiswa prodi Sistem Komputer, responden diambil secara acak kepada mahasiswa yang sudah pernah mengambil mata kuliah Internet of Things sebelumnya. Metode uji coba kelompok kecil kurang lebih sama dengan uji coba sebelumnya, hanya saja uji kali ini melibatkan 9 orang dan itu sudah dipandang cukup untuk melakukan uji coba modul pembelajaran. Setelah hasil rekapitulasi angket uji coba kelompok kecil dikonversi, rentang rerata skor diperoleh $(86,67 \&)$ hasil tanggapan uji coba kelompok kecil ada pada kualifikasi layak/baik tidak perlu direvisi.

Pada saat uji coba kelompok kecil diberikan beberapa saran dan komentar mengenai produk, diantaranya: produk yang dikembangkan sangat membantu proses pembelajaran dan meningkatkan motivasi untuk belajar, modul yang dikembangkan sangat menarik dan up to date dengan teknologi yang sedang berkembang sekarang ini, dengan adanya modul pembelajaran ini, membuat saya (mahasiswa) lebih cepat memamahi materi perkuliahan dan praktek, dikarenakan terdapat pengaplikasi langsung mengenai materi yang diajarkan.

\section{SIMPULAN DAN SARAN}

Proses pembuatan modul pembelajaran menggunakan langkah-langkah dari Depdiknas dan disusun menggunakan software Microsoft Word dengan silabus sebagai panduan penyusunan. Pengembangan modul pembelajaran disesuaikan dengan kebutuhan pembelajaran melalui tahapan penelitian pengembangan yang dikembangkan oleh ADDIE, antara lain: 1) penelitian analisis, 2) desain, 3) pengembangan, 4) implementasi, dan 5) evaluasi, pengembangan produk berupa modul pembelajaran, diharapkan menjadikan proses dan hasil belajar mahasiswa menjadi lebih optimal dengan menerapkan metode belajar mandiri (student center).

Hasil pengujian pengembangan perangkat pembelajaran mikrokontroler ke ahli isi menunjukkan bahwa materi pembelajaran pada modul pembelajaran sudah sesuai dengan silabus pada mata kuliah Internet of Things. Hasil uji coba perorangan yaitu $91.94 \%$, dan uji coba kelompok kecil yaitu $86.67 \%$, hasil tersebut memberikan hasil yang memuaskan terhadap produk yang dikembangkan terlihat para mahasiswa sangat tertarik belajar dengan sesuatu yang baru dan menarik. Hasil pengembangan dan penerapan dalam proses pembelajaran memberi tanggapan yang baik dari mahasiswa selama penggunaan modul pembelajaran. mahasiswa tertarik mencoba produk dan antusias mengikuti proses pembelajaran.

Pada penelitian ini diterapkan hanya pada satu matakuliah yaitu Internet of Things maka disarankan untuk pengembangan selanjutnya dapat diterapkan pada beberapa matakuliah yang memiliki potensi yang dapat dikembangkan. Pengembangan modul pembelajaran diharapkan menjadi penggerak bagi para pendidik untuk dapat mengembangkan inovasi-inovasi terbaru kedalam pembelajaran baik berupa media atau hal yang lain yang bersifat kontekstual, dimana dengan adanya inovasi pengajar dituntut keluar dari zona nyaman untuk dapat menghasilkan suatu karya bagi dunia pendidikan. 


\section{UCAPAN TERIMAKASIH}

Ucapan terimakasih ditujukan kepada Lembaga Penelitian dan Pengabdian Masyarakat yang telah memberikan kesempatan untuk melakukan penelitian PPDS dengan nomor kontrak 15/04/LPPM/X/2018 dan institusi STMIK STIKOM Indonesia sebagai penyandang dana penelitian ini

\section{DAFTAR PUSTAKA}

[1] E. Jayanti, "PENGEMBANGAN MODUL PEMBELAJARAN KIMIA BERBASIS POE (PREDICT, OBSERVE, EXPLAIN) PADA MATERI LARUTAN ELEKTROLIT DAN NON ELEKTROLIT," Pendidik. Kim., vol. 2, no. 2, pp. 1-11, 2018.

[2] A. A. Gde. Ekayana. Naswan Suharsono. I Made Tegeh, "Mikrokontroler Berbasis Advance Virtual Risc ( Avr ) Dalam Mata Pelajaran Teknik," e-Journal Progr. Pascasarj. Univ. Pendidik. Ganesha Progr. Stud. Teknol. Pembelajaran, vol. 3, 2013.

[3] R. Ramadhana and A. Hadi, "Pengembangan Modul Pembelajaran Matematika Berbasis Learning Cycle 7E dengan Pendekatan Saintifik," J. IIm. Pendidik. Mat., vol. 1, no. 1, pp. 45$52,2018$.

[4] U. Kalsum et al., "Pengembangan Modul Pembelajaran Biologi Materi Ekosistem Berbasis Pendekatan Contextual Teaching And Learning (CTL)," LENTERA Pendidik., vol. 21, no. 1, pp. 97-109, 2018.

[5] I. P. G. A. Mahendra, I. G. Nurhayata, and K. U. Ariawan, "Pengembangan Modul Prototipe Mcb Elektronik Sebagai Media Pembelajaran Prakarya Dan Kewirausahaan Siswa Kelas Xi Sma Negeri 1 Singaraja," J. Pendidik. Teknol. dan Kejuru., vol. 14, no. 2, pp. 168-177, 2017.

[6] W. Sanjaya, Strategi pembelajaran berorientasi standar proses pendidikan. Jakarta: Kencana Prenada Media Group, 2009.

[7] Depdiknas, Penulisan Modul. Jakarta, 2008.

[8] M. P. A. Hukeri et al., "Review paper on iot based technology," Int. Res. J. Eng. Technol., vol. 4, no. 1, pp. 1580-1582, 2017.

[9] A. A. G. Ekayana, "Pengembangan Bahan Ajar Aplikasi Sensor Transduser Berbantuan Media Trainer Mikrokontroler," S@Cies, vol. 7, no. 1.pp.69-73, 2018.

[10] A. Susilo, Siswandari, and Bandi, "Pengembangan Modul Berbasis Pembelajaran Saintifik Untuk Peningkatan Kemampuan Mencipta Siswa Dalam Proses Pembelajaran Akuntansi Siswa Kelas XII SMA N I Slogohimo 2014," J. Pendidik. IImu Sos., vol. 26, no. 1, 2016.

[11] P. I. Fahrizal and T. Wiyanto, "PENGGUNAAN MODUL PEMBELAJARAN BERBASIS KOMPUTER (CAD) UNTUK MENINGKATKAN HASIL BELAJAR DI SMK NEGERI 3 JOMBANG," JPTM, vol. 4, no. 2, pp. 85-92, 2016.

[12] A. Siahaan, "PENGEMBANGAN MODUL PEMBELAJARAN PADA KOMPETENSI AUTOCAD SISWA SMK," J. Teknol. Inf. dan Komun. dalam Pendidik., vol. 4, no. 1, pp. 13-23, 2017. 